\title{
RESEARCH
}

\section{Polar response particles in French as remnants of ellipsis}

\author{
Jérémy Pasquereau \\ University of Surrey, Stag Hill, Guildford, GB \\ j.pasquereau@surrey.ac.uk
}

\begin{abstract}
Polar response particles have been at the center of lively debates in the recent and not so recent literature. One of these debates concerns the syntax of these particles, in particular whether they are pure sentential proforms or involve ellipsis. This paper examines the syntax of the French polar response particles oui, non, and si in embedded contexts. On the basis of these particles' sensitivity to finiteness, obviation, and antilogophoricity in embedded clauses, it argues that they are better analyzed as remnants of ellipsis.
\end{abstract}

Keywords: polar response particles; oui; non; si; ellipsis

\section{Introduction}

This paper is concerned with the syntactic structure of sentences containing polar response particles (PRPs) as in (1): the PRP responses to (1A) are interchangeable as far as their truth-conditional content is concerned whether the PRP appears on its own (1B1) or with a following clause (1B2).

$$
\begin{aligned}
& \text { A: Est- ce qu' il joue du piano? } \\
& \text { is it that he plays of.the piano } \\
& \text { 'Does he play piano?' }
\end{aligned}
$$

B1: Je crois que non.

I believe that no

'I think that he does not play piano.'

B2: Je crois que non, il ne joue pas du piano. I believe that no he NEG plays NEG of.the piano 'I think that he does not play piano.'

It contributes to the debate about whether yes/no particles are better analyzed as pure proforms or involve syntactic structure (Kramer \& Rawlins 2011; Krifka 2013 a.o.) by examining data from French polar response particles in embedded contexts. Indeed, the recent debate on whether PRPs are pure proforms or remnants of ellipsis has mostly focussed on English and German, two languages where embedded PRPs are not possible (at least not in the same way). ${ }^{1}$ Looking at PRPs in embedded contexts gives access to diagnostics to probe their syntax and answer this question.

\footnotetext{
${ }^{1}$ In both English and German, PRPs on their own cannot be embedded under the complementizer that or dass, whereas French allows their embedding under que. On the other hand, it is not the case that PRPs in English and German cannot be embedded at all: in both languages they can be embedded in the antecedent of a conditional in response to a question, e.g. if yes or wenn ja. To the extent that the sequence $I$ think yes
} 
On the basis of new syntactic diagnostics made available by embedding, I argue that French embedded PRPs that appear without a full clause to their right are better analyzed as remnants of ellipsis rather than pure proforms. That is, the anaphoric nature of PRPs does not stem from their being anaphors themselves, rather it stems from conditions under which ellipsis of their prejacent clause happens. Not only is an ellipsis-based analysis as able to model certain behaviors of PRPs as are the proform-based analyses in Ginzburg \& Sag (2000) and Krifka (2013) (though see section 5), but it also successfully captures the behavior of embedded PRPs where a pure proform-based analysis cannot. In other words, I bring new arguments that (1B1) and (1B2) in response to (1A) have the same underlying syntactic structure.

The generalizations reported in this paper are based on the judgements of the author and of ten non-linguist French native speakers from the area around the city of Nantes, France. Readers should be aware that these judgements are not however shared uniformly across other native speakers of French: for instance, while one anonymous reviewer agrees with the judgements reported in this paper, another (and reportedly four consultants of theirs) do not share the reported judgements for examples (22), (29B3) and (29B4).

The structure of this paper is the following. In section 2 I give relevant background information on PRP responses in French and previous approaches to PRPs in general. In section 3, I present three arguments that PRPs on their own (without a clause to their right) involve ellipsis and cannot be just proforms. Section 4 presents my analysis of the structure of French embedded PRPs and argues that PRPs always come with a clauseovert or covert-that is semantically identical to a clause in the preceding discourse (modulo negation). In section 5, I flag a for now unresolved contrast for the ellipsis analysis of PRPs. Section 6 concludes.

\section{Background}

This section starts by presenting French polar response particles (PRPs), gives a brief overview of what analyses have been given for polar response particles across languages, and concludes by discussing why I focus on embedded PRPs specifically.

\subsection{Polar response particles and their distribution in French}

In French one can respond to a question (2A1) or an assertion (2A2) with an utterance containing a polar response particle (PRP). In the paper, I restrict the illustration of the discussion to responses to questions for the sake of saving space but the conclusions that will be drawn also apply to antecedent assertions. Those utterances can take several shapes: PRPs can be embedded or not, whether they are bare- "bare PRPs"- as in (2B1/B3) or at the edge of a full clause- "clause-peripheral PRPs"—as in (2B2/B4).

a. Discourse initiative (question or assertion)
A1: Est- ce qu' ils vont venir? is it that they go come
'Are they going to come?'
Question

is acceptable-it is not acceptable for all speakers as an anonymous reviewer pointed out-one could argue that it is a case of embedding with the English silent complementizer. On the other hand, even for speakers who accept this construction, there is reason to doubt that such cases are really cases where the PRP yes is embedded since, unlike in French, such a sequence cannot be made into a question (cf. (ia) and (ib); Vincent Homer, p.c.).

(i) a. Est -ce que tu penses que oui ?

is it that you think that yes

'Do you think it is the case?'

b. *Do you think yes? 
A2: Ils vont venir.

they go come

'They are going to come.'

Assertion

b. Response (matrix or embedded; bare or clause-peripheral)

B1: Non

no

'No.' (= they will not come)

B2: Non, ils ne vont pas venir.

no they NEG will NEG come

'No, they won't.'

B3: Je pense que non.

I think that no

'I don't think so.' ( = I think that they will not come).

B4: Je pense que non, ils ne vont pas venir.

I think that no they NEG will NEG come

'I don't think they will.'

Clauses containing a bare PRP are sufficient to answer a question: for instance in (2B1/B3), the clause containing the PRP non denotes they are not going to come, that is the negation of the question nucleus. In cases where a particular phrase is given prominence (e.g. contrastive focus, topicalization), it can appear as a fragment to the left of the PRP in each of the four configurations above (3). ${ }^{2}$ In this case, the embedded clause containing the PRP also denotes the negation of the question nucleus, after the fragment has been substituted for the argument given prominence in the question nucleus.

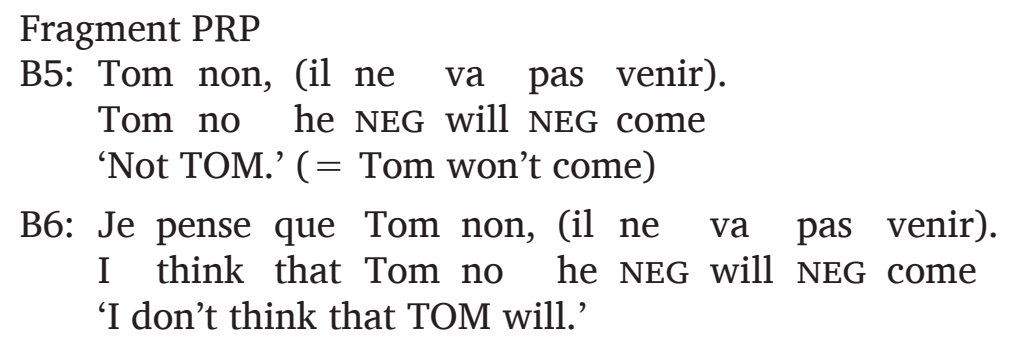

Example (4) summarizes the terms used to describe each configuration when they are not embedded. I use the term "clause" when I do not want to commit to whether the clause following a PRP is a prejacent or a coda (see section 4.2).

$$
\begin{aligned}
& \text { A: Est -ce qu' ils vont venir? } \\
& \text { is it that they go come } \\
& \text { Will they come? }
\end{aligned}
$$

B1: Non.

$$
\text { 'No.' ( = they won't) }
$$

\footnotetext{
$\overline{2}$ The fragment can belong to a variety of syntactic categories e.g. CPs (iB2) (Morris 2008; Servidio 2014).

(i) A: Est- ce que le fait que mes parents viennent la dérange ? is it that the fact that my parents come her bothers 'Does my parents' coming bother her?'

B1: Je pense que, que ta mère vienne, non mais que ton père vienne, oui. I think that that your mother come no but that your father come yes 'I think that your mother's coming does not, but your dad's does.'
} 
B2: Non, ils ne viendront pas. 'No, they won't.'

B3: Non, ils sont occupés. 'No, they are busy.'

B4: Tom non. 'Not TOM.'

B5: Tom, non il ne viendra pas. 'Not TOM, he won't.'

B6: Tom non, il est occupé. 'Not TOM, he's busy.'
Clause-peripheral PRP /

PRP with (overt) prejacent clause

PRP with coda

Fragment PRP

Clause-peripheral fragment PRP / Fragment PRP with (overt) prejacent clause

Fragment PRP with coda

\subsection{Previous analyses of Polar Response Particles}

Polarity particles have been at the center of lively debates in the recent and not so recent literature. In some of these debates the issue of "proform" vs. "ellipsis" is central, while in others the central issue is how these particles are interpreted. The most recent debate is between Farkas and Roelofsen on the one hand, and Krifka and collaborators on the other. The two approaches involved differ with respect to the two parameters in (5).
a. Ellipsis vs. pro-form
b. Information encoded in PRPs

This paper is about the first parameter and is thus meant to be compatible with any of the ellipsis-based proposals for parameter $b$.

\section{Ellipsis vs proform}

Work on the first parameter has so far focussed on matrix PRPs ${ }^{3}$ with the notable exception of Authier (2013) whose focus is on embedded PRPs in French. Some accounts analyze matrix PRPs as having an elidable full clause as their sister (Laka 1990; Morris 2008; Holmberg 2011; Kramer \& Rawlins 2011; Thoms 2012; Authier 2013; Holmberg 2013; Servidio 2014) while others analyze them as being purely anaphoric sentential proforms (Ginzburg \& Sag 2000; Krifka 2013). Others still do not commit to either approaches (Roelofsen \& Farkas 2014). The results of this research can readily be extended to the embedded domain.

On the proform analysis, bare English yes and no and German ja and nein are indeed bare just like pronouns, and fragment PRPs (3B5/B6) are, Krifka (2013) suggests, hanging topic structures. In such cases, the idea is that the PRP picks up the background of the question (a property, e.g. $\lambda x_{.} \neg(\mathrm{x}$ is coming)) and applies it to the topic, e.g. Tom. In this analysis, clause-peripheral cases are analyzed as the juxtaposition of two utterances or assertive speech acts: one containing a polar response particle and another one containing a clause.

Under the ellipsis analysis, Holmberg (2001; 2013); Kramer \& Rawlins (2010; 2011) argue that in English yes and no are adverbs that always come with a TP which can be optionally elided under identity with a constituent in the preceding discourse. Semantic identity is taken to be Merchant (2001)'s e-givenness notion which is defined in section 4.1. Fragment-peripheral PRPs are then the result of phrasal movement to a position higher than the PRP. In other words, for them, bare, fragment-peripheral, and clauseperipheral cases have the same structure. As a consequence of this equivalence, Holmberg

\footnotetext{
${ }^{3}$ French matrix PRPs have been looked at in Hoeybye (1939); Cohen (1952); Zwanenburg (1967); Wunderli (1974); Wilmet (1976); Pohl (1976); Plantin (1982); Diller (1984); Lebaud (1995); Kerbrat-Orecchioni (2001); Schapira (2012); Morris (2008); Takagaki (2014).
} 
(2001; 2013) and Kramer \& Rawlins (2011) but other work as well (Farkas 2011) more or less implicitly take bare and clause-peripheral cases to inform each other and the semantics and syntax of polar response particles as a whole.

In the literature favoring the ellipsis analysis and in the literature favoring the proform analysis, we find plausibility arguments that show that both types of analysis can model attested interpretive patterns. For instance, Kramer \& Rawlins (2011) show that if we assume that yes and no in English involve ellipsis then two patterns of data straightforwardly follow: negative neutralization ${ }^{4}$ and the fact that yes and no can appear bare or followed by a full clause with no redundancy. But these patterns can also be explained by the proform analysis (Krifka 2013).

\section{Previous arguments for ellipsis/against pro-form view}

In addition to the papers mentioned above, ellipsis approaches have been argued or assumed for PRPs in specific languages. In Spanish Vicente (2006) points out that the binding contrasts in (6) follows from an ellipsis analysis of fragment PRPs but not from a proform analysis.

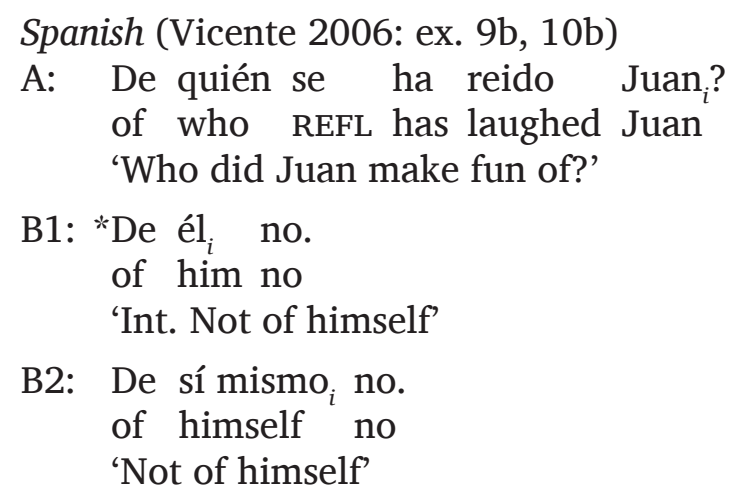

In Italian, Servidio (2014) shows that the fragment in bare fragment PRPs (polarity fragments in his terminology) is sensitive to syntactic islands. He proposes that the islandsensitivity (among other properties of Italian fragment PRPs) is expected if the fragment is an instance of Clitic Left Dislocation. However, as he notes, there is a debate as to whether Clitic Left Dislocation in Italian involves movement (Cecchetto 1999; Frascarelli 2004), and so whether this argument goes through for Italian PRPs ultimately depends on the analysis of Clitic Left Dislocation in Italian.

Romanian has three PRPs which Roelofsen \& Farkas (2014) analyze as follows: ba marks that a response has the reverse polarity from its antecedent, $n u$ marks that the response has negative polarity and $d a$ marks that the response has positive polarity. Thus a positive response to the negative question in (7) must contain the reverse particle $b a$ and an element realizing the positive polarity of the response, either the particle $d a$ in (B1) or the

\footnotetext{
${ }^{4}$ The term "negative neutralization" was first coined in Kramer \& Rawlins (2011) to refer to a particular interpretive pattern of yes and no in response to positive and negative questions. Whereas yes and no have different interpretations in response to a positive question ( $c f$. (iB1) and (iB2)), this interpretive difference is "neutralized" in response to the negative question in (ii) ( $c f$. (iiB1) and (iiB2)), hence "negative neutralization".
}

(i) A: Is Alfonso coming to the party?

B1: Yes. ( = he is coming to the party)

B2: No. (= he is not coming to the party)

(ii) Is Alfonso not coming to the party?

B1: Yes. ( = he is not coming to the party)

B2: No. (= he is not coming to the party) 
full clause in (B2). In other words, in Romanian, the polarity of the response itself must always be overtly realized, whether by a particle or by an overt prejacent. As Roelofsen \& Farkas (2014: 40) note, this rule is most naturally stated if Romanian PRPs always involve a prejacent (which may be elided).

\section{(7) Romanian (Roelofsen \& Farkas 2014: ex. 101)}
$\mathrm{A}: \mathrm{Nu}$ a telefonat Paul?
NEG has called Paul
'Did Paul not call?'
REV POS
'Yes, he DID.'
B1: Ba da.
B2: $\mathrm{Ba}, \mathrm{a}$ telefonat.
REV has called
'Yes, he did call.'
B3: *Da.
POS
'Int. Yes, he DID.'
B4: *Ba.
REV
'Int. Yes, he DID.'

Goodhue \& Wagner (2018:10) provide another argument due to M. Rochemont against the proform analysis and in favor of the ellipsis analysis on the basis of English data. In response to a polar question (e.g. Does Jane like coffee?), they observe that when a PRP is followed by a full clause, it is possible to deaccent the clause and stress the PRP (YES, she likes coffee). Crucially, however, this shift in prominence is not possible across a sentence boundary, as can be seen when the PRP is replaced by a semantically-equivalent short clause (\#She DOES, she likes coffee). Since Krifka (2013)'s account assumes that yes denotes a speech act, i.e. a separate sentence from the prejacent that can sometimes follow it, this pattern is not compatible with his proform analysis of yes/no. In the next paragraph, I give an overview of pro-ellipsis arguments given on the basis of French data specifically.

\section{Specifics on French}

Morris (2008) argues that clauses containing bare PRPs involve a particular type of ellipsis ("type A" ellipsis in Hankamer 1979) on the basis that, in the variety of French she studies, the PRPs and the presumed ellipsis they involve are unbounded (8) and antecedent island-insensitive. By contrast, negative stripping which is bounded and antecedent-island sensitive is argued to have all the properties of "type B" ellipsis in Hankamer (1979).

(8) a. PRP (polarity ellipsis in Morris's terminology; Morris 2008: ex. 20)

Jean aime le chocolat, et je crois que Pierre a dit que Marie non.

Jean likes the chocolate and I believe that Pierre has said that Marie no 'Jean likes chocolate, and I believe that Pierre said that Marie does not like chocolate.'

b. Negative stripping (Morris 2008: ex. 21)

*Jean aime le chocolat, et je crois que Pierre a dit que pas Marie.

Jean likes the chocolate and I believe that Pierre has said that NEG Marie 'Int. Jean likes chocolate, and I believe that Pierre said that Marie does not like chocolate.' 
Authier (2013) also argues for ellipsis on the basis that (embedded) PRPs only occur under predicates selecting for finite clauses-an argument which I further discuss and elaborate on in section 3.1. In addition, he shows that, unlike English so/not, they allow syntactic extraction (9), and that they can be used as the left conjunct of a CP coordination (10; see also Dagnac 2019 for a discussion of Morris 2008 and Authier 2013's arguments). These two contrasts follow if French embedded PRPs involve ellipsis whereas so/not do not.

Extraction

a. Authier (2013: ex. 67)

A: Est -ce qu' il a parlé à Robert ou à Christine ? is it that he has spoken to Robert or to Christine 'Did he talk to Robert or Christine?'

B: Je crois qu' à Christine, oui. I believe that to Christine yes 'I think that to Christine, yes.'

b. Authier (2013: ex. 68)

A: Did he talk to Robert or Christine?

B: *I think (that) to Christine, so/not.

(10) Coordination

a. Authier (2013: ex. 69)

A: $\mathrm{Tu}$ crois qu' on devrait couper dans notre budget ?

You believe that we should cut in our budget 'Do you believe we should cut our budget?'

B: Je pense [ que oui ] et [ que ça fait longtemps qu' on I think that yes and that it makes long that we aurait dû le faire ].

have.COND must.PTCP it do ]

'I think we should and that we should have done it a long time ago.'

b. Authier (2013: ex. 70)

A: Do you believe we should cut our budget?

B: ?? I think [ so ] and [ that we should have done it a long time ago ].

Focussing after Authier (2013) on embedded PRPs, I present new syntactic arguments and deepen an existing one from Authier (2013) that French PRPs are remnants of ellipsis and not pure proforms. Following Holmberg (2001); Kramer \& Rawlins (2010; 2011); Holmberg (2013); Pasquereau (2018; 2020), I show that clauses containing an embedded PRP can be derived from the same underlying structure (11) modulo ellipsis.

Ellipsis hypothesis

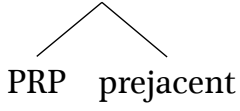

\subsection{Why focus on embedded PRPs?}

Following pioneering work on English yes and no particles by Wiltschko (2017), Pasquereau (2018) shows that matrix PRPs in French have a far wider range of uses than their embedded counterparts: that is, matrix PRPs are used as what Wiltschko calls "agreement" or "disagreement" markers respectively when they respond to discourse initiatives other than polar questions and assertions.

For instance, matrix oui can be used in response to a wh-question, as in (12B): B's response to A's question conveys that B also wants to know the answer to the question asked by 
A-that B thinks the question asked by A is a good question in the given situation. This is significant as oui cannot be used out of the blue.

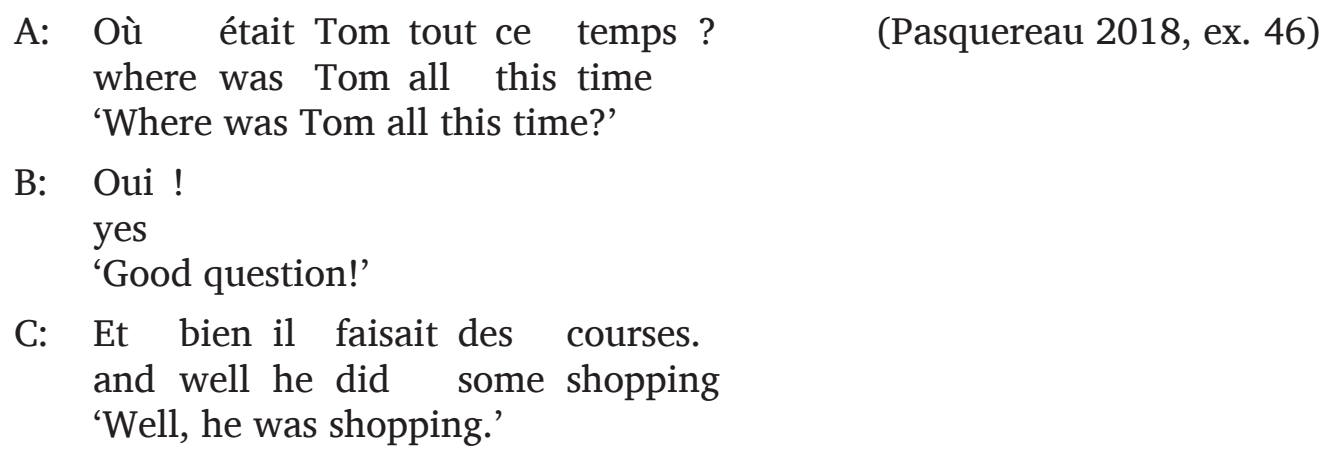

However, a PRP response to a wh-question cannot be embedded. Example (13) is a conversation among three persons: A asks a wh-question, B can react to A's question with B2 but not an embedded PRP (B1), and finally $\mathrm{C}$ gives a response to the wh-question. Only B2 is a felicitous reaction to $\mathrm{A}$.

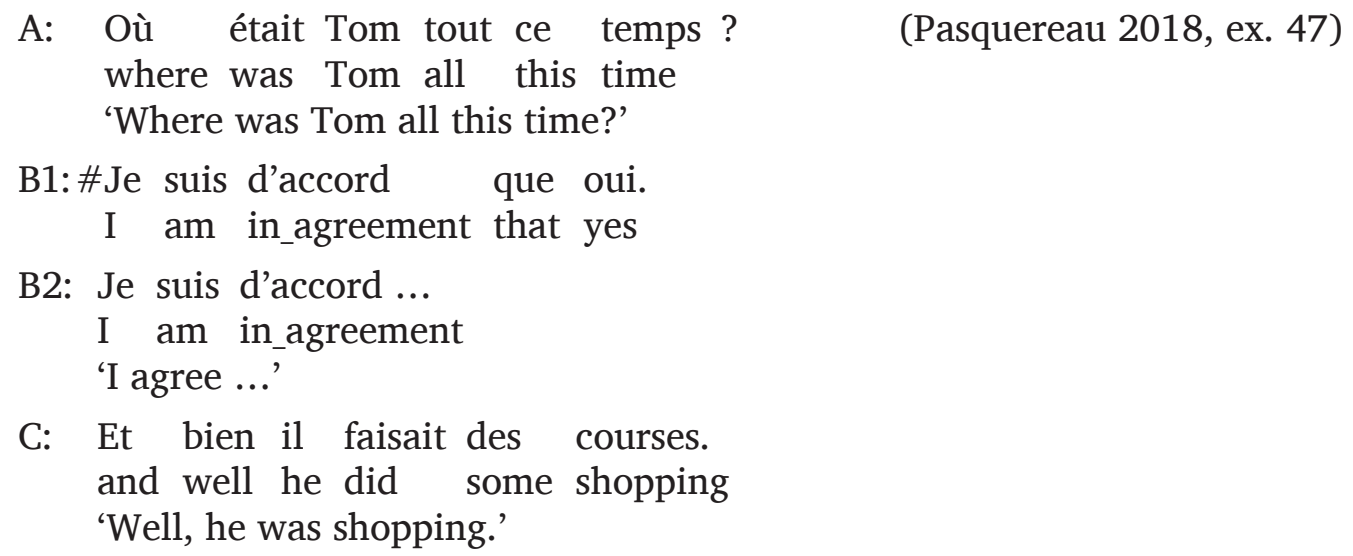

Wiltschko (2017) models these uses in English by extending the elliptical structure to pragmatic agreement by proposing that yes and no can be merged in a speech act layer-in the specifier of GroundP-, when they are used as (dis)agreement markers (14), or below $\mathrm{CP}$, when they are used as answers (15).

(14) The syntax of PRPs in their (dis)agreement function (Wiltschko 2017)

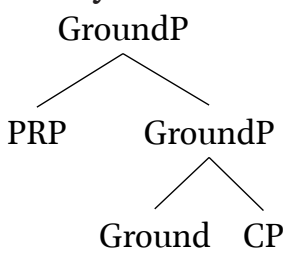

(15) The syntax of PRPs in their answering function (adapted from (Wiltschko 2017))

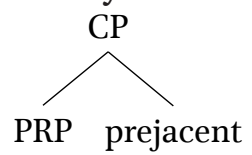

I assume that embedded PRPs and at least a subset of matrix PRPs in French have the same basic syntax (to be made more specific in section 4). Assuming Wiltschko's structure 
for French matrix PRPs, the difference in the uses of matrix and embedded PRPs in French stems from the fact that PRPs cannot be embedded with their speech act layer. Thus, focussing on embedded PRPs offer two advantages when studying their syntax: they allow us to steer clear from potential confounding factors due to the speech act layer and they open further diagnostics as I show in section 3.

\section{Conditions on embedding}

PRPs can be embedded under predicates of speech (murmurer 'mutter', chuchoter 'whisper', ...), predicates of thought (penser 'think', croire 'believe', avoir l'impression 'have the feeling' ...), predicates of likelihood (être possible 'be possible', être probable be likely, peut-être 'maybe', sans doute 'no doubt', ...), and some predicates of preference: préférer 'prefer', espérer 'hope', souhaiter 'hope', ... (Authier 2013; Pasquereau 2018). ${ }^{5}$ In addition, embedded PRPs are sensitive to the polarity of their environment (Authier 2013)—they

\footnotetext{
${ }^{5}$ Several of the judgements I report are different from the ones reported in the literature (Morin 1985: 799, Rowlett 2007 and Authier 2013). Morin (1985: 799) and Rowlett (2007) report that PRPs cannot be embedded under predicates that select for the subjunctive mood and Authier (2013) reports that PRPs cannot be embedded under bouletic predicates. Consistent with their generalizations, all three authors report that the string je souhaite que oui is not acceptable/grammatical. This is not what I have found when probing my intuitions and those of my consultants. To further confirm some of them, I included a few relevant sequences as filler items in two acceptability judgment experiments. The purpose of these experiments had nothing to do with PRPs (it was designed to test structures containing de-NP phrases in French). The filler items included the PRP oui embedded under a bouletic verb as in (i).
}

(i) a. Je ne sais pas si Esteban va venir à la fête mais j' espère que oui. I NEG know NEG if Esteban goes come to the party but $I$ hope that yes

b. Je ne sais pas si Aurélien va réussir son examen mais je souhaite que oui. I NEG know NEG if Aurélien goes pass his exam but I sOUHAITER that yes

c. Je ne sais pas si Claire va venir en vacances avec nous mais je veux que oui. I NEG know NEG if Claire goes come on holiday with us but I want that yes

d. Je ne sais pas si Laurence va aller à la piscine avec nous mais je voudrais I NEG know NEG if Laurence goes go to the pool with us but I want.COND que oui. that yes

The first questionnaire study (50 participants) was online: participants saw the sentence presented to them in chunks (Rapid Serial Visual Presentation) and they were given 2 seconds to categorize the sentence as acceptable (1) or unacceptable (0). The second questionnaire study (52 participants) was offline: participants could take as much time as they wanted to read and judge the sentence by rating it on a Likert scale from 1 (unacceptable) to 7 (acceptable). I report the mean rating for each embedding verb along with the standard error in parentheses (ii).

(ii) Rating of $V$ que oui sequences

$\begin{array}{lll}\text { V } & \text { online (1 or 0) } & \text { offline (1-7) } \\ \text { espérer 'hope' } & 1(0) & 6.61(.08) \\ \text { souhaiter } & .98(.02) & 6.25(.15) \\ \text { vouloir 'want' } & .33(.07) & 3.88(.26) \\ \text { voudrait 'would want' } & .77(.06) & 5.23(.23)\end{array}$

I do not have an explanation for the differences in judgements that Morin/Rowlett/Authier and I report. It is possible that there is inter-speaker variation in which case we just happened to tap into different dialects. It is also possible, that the acceptability of a PRP under vouloir depends on wider conditions. For instance, Pasquereau 2018 shows that when vouloir is used as a reportative verb, PRP embedding is perfectly acceptable. Furthermore, an anonymous reviewer reports the contrast in (iii) -which I have not tested on my consultants. It is likely that the environment in which vouloir que oui is embedded, the conditional clause, has an effect. I leave this for further research.

(iii) a ?*Ma fille ne veut pas qu' on parte en vacances cette année, mais moi, je my daughter NEG wants NEG that we go.SUBJ on holiday this year but me I veux que oui. want that yes 'Int. My daughter doesn't want to go on vacation this year but I do.' 
have the distribution of Positive Polarity Items (Pasquereau 2018)—and require a particular contrast condition to hold (Pasquereau 2018).

Syntactically, those predicates can be verbs, adjectives, adverbs, or even nouns (16).

A: Est- ce que se laver apporte des maladies ? is it that REFL wash bring some diseases 'Does bathing bring diseases?'

B: L' opinion que oui est encore prévalente. the opinion that yes is still prevalent 'The opinion that washing brings diseases is still prevalent.'

Polar response particles in French can also be embedded under the complementizer $s i$ 'if' in the antecedent of a conditional construction (17).
A: Est -ce que Tom va venir ?
Is it that Tom goes come
'Is Tom going to come?'

B1: Si oui, dis lui d' apporter du vin.

if yes tell him to bring some wine

'If so, tell him to bring wine.'

B2: Si non, fais -moi penser à lui donner de nos restes.

if no make me think to him give of our leftovers

'If not, remind me to give him some of our leftovers.'

They are also found in result clauses (18).
A: Est -ce que tu prends des notes?
is it that you take some notes
'Are you taking notes?'
B: Je m' ennuie tellement que oui.
I 1SG.REFL am_bored so_much that yes
'I'm so bored that (yes) I am.'

Authier (2013) proposes an account of the selectional restrictions on embedded PRPs in an ellipsis-based clause-typing account (more detail is given in section 4.1). This paper provides new arguments for ellipsis. It is thus compatible with Authier (2013)'s account.

\section{Arguments for an ellipsis-based account}

In this section I argue that bare and fragment-peripheral PRPs involve an elided constituent to their right. I present evidence that there is ellipsis and that embedded PRPs are not pure proforms.

b. Il n' est pas du tout certain que le maire nous en donnera l' autorisation. it NEG is NEG at all certain that the mayor us of.it give.FUT the authorization Si on veut que oui, il va falloir justifier notre requête de manière convaincante. if we want that yes it goes must justify our request of manner convincing 'It is far from certain that the mayor will give us authorization. If we want him to, we are going to have to justify our request in a convincing manner.' 


\subsection{Bare PRPs may only replace finite clauses}

As shown by Authier (2013: 372), of the two complementizers - que for finite clauses (19B1) and de for non-finite (infinitival) clauses (19B2) - PRPs are only ever embedded under que (19B3) and never under de (19B4), even when a verb allows both complementizers, as is the case with promettre 'promise' in (19).

$$
\begin{aligned}
& \text { A: Est -ce que tu vas venir ? } \\
& \text { Is it that you go come } \\
& \text { 'Are you going to come?' }
\end{aligned}
$$

B1: J' ai promis que je vais venir.

I have promised that I go come

'I promised that I'll come.'

B2: J' ai promis de venir.

I have promised to come

'I promised to come.'

B3: J' ai promis que oui.

I have promised that yes

'I promised that I would.'

B4: *J' ai promis de oui.
I have promised to yes

Proforms in French do not embed while PRPs do. In response to the assertion in (20A), it is possible to respond with a clitic proform (B1) or, marginally, with a full (i.e. nonphonologically deficient) proform (B3), however, these proforms cannot be embedded under que as (20B2) and (20B4) show. ${ }^{6}$

A: Marcel me dit que tu as un caractère difficile. Marcel me says that you have a character difficult 'Marcel tells me that you're difficult.'

B1: Ah bon ! Et bien, ça me fait de la peine qu'il le pense. oh good and well this me does of the sorrow that he it 'Oh really! Well, it makes me sad that he should think so.'

B2: *Ah bon! Et bien, ça me fait de la peine qu'il pense que le.

\footnotetext{
${ }^{6}$ Thanks to an anonymous reviewer for the example. Interestingly, the acceptability of ça in response to a question is significantly lower. Thus in response to (iA), (iB1) is perfectly acceptable whereas (iB3) is only marginally acceptable. Importantly however, the lower acceptability of (B3), compared to (B1) is caused by the illocutionary force of the antecedent: (B1) and (B3), where le/ça respond to an assertion, are equally perfectly acceptable (anonymous reviewer, p.c.).
}

(i) A: Est- ce qu' il va quitter Marie ?

is it that he goes leave Marie

'Is he going to leave Marie?'

B1: Je sais que tu l' espères mais c' est peu probable. I know that you it hope but it is little probable 'I know that you hope so but it's not very likely.'

B2: "Je sais que tu espères que le mais c'est peu probable

B3: 'Je sais que tu espères ça mais c' est peu probable.

I know that you hope this but it is little probable

'I know that you hope this but it's not very likely.'

B4: *Je sais que tu espères que ça mais c'est peu probable. 
B3: Ah bon ! Et bien, ça me fait de la peine qu' il pense ça. Oh good and well this me does of the sorrow that he thinks this 'Oh really! Well, it makes me sad that he should think so.'

B4: *Ah bon! Et bien, ça me fait de la peine qu' il pense que ça.

Uncontroversial sentential proforms in French cannot embed while PRPs can. This is easily accounted for in an ellipsis approach. Moreover, sentence-level proforms (le, en, y, cela, ça) are not sensitive to whether a predicate embeds finite or non-finite clauses. Thus in (21) where the response with the non-finite infinitival clause is the only possibility ( $c f$. (21B1) vs. (21B2)), the proform le is possible (21B3).

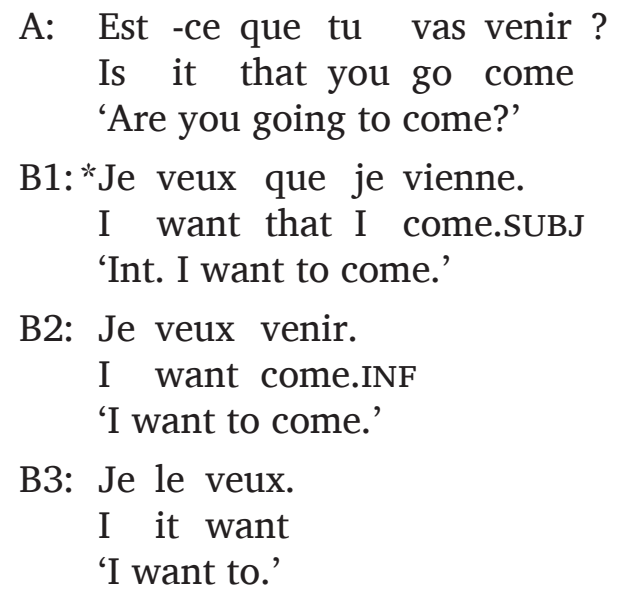

In (22) where the response with the finite clause is the only possibility with the intended meaning ( $c f$. (22B1) vs. (22B2)), the proform le is possible (22B3) as well.

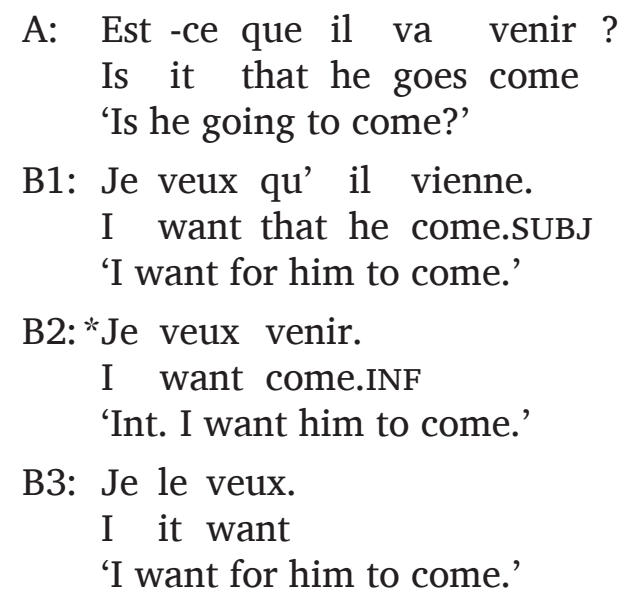

In conclusion, the possibility to use a sentential proform in French is not tied to the finite/non-finite distinction, whereas the possibility to use a PRP is. If PRPs are the remnants of the elision of a full (finite) clause, their sensitivity to finiteness is natural. To see this, consider the verb paraittre 'seem' which can appear in two constructions.

In construction 1 exemplified in (23B1), the subject does not raise and the complement of the verb is a finite clause. Bare PRPs can be embedded in the latter construction as the acceptability of (23B2) and (23B3) shows.

(23) A: Est- ce qu' ils se sont réconciliés avec ses parents ? is it that they reconciled with her parents

'Did they reconcile with her parents?' 
B1: Il paraît qu' ils se sont réconciliés. it seems that they REFL be reconciled 'It seems that they reconciled.'

B2: Il paraît que oui. it seems that yes 'It would seem so.'

B3: Il paraît qu' avec sa mere oui mais avec son père non. it seems that with her mother yes but with his father no 'It seems that they did with her mother but not with her father.'

But in construction 2, the subject raises and the complement of the verb can only be nonfinite ( $c f$. (24B1) and (24B2)). A bare PRP cannot be embedded there (24B3/B4), even if the complementizer is omitted.

$$
\begin{aligned}
& \text { B1: Ils paraissent s' être réconciliés. } \\
& \text { they seem REFL be reconciled.INF } \\
& \text { 'They seem to have reconciled.' }
\end{aligned}
$$

B2: *Ils paraissent qu' ils se sont réconciliés. they seem that they REFL be reconciled

B3: *Ils paraissent (que) oui. they seem that yes

B4: "Ils paraissent (qu') avec sa mere oui mais avec son père non. they seem that with her mother yes but with his father no

Building on Authier (2013), this section has shown that the entailment in (25) holds for every attitude verb $P$.

\section{Finiteness Generalization}

If a verb $P$ in a specific construction exclusively selects for a non-finite clause, then $P$ cannot embed a bare PRP

Embedding provides evidence that bare and fragment-peripheral particles do involve ellipsis because they are only possible where a finite clause is possible. In the next section, I provide another argument that there is a correlation between finiteness and the possibility to embed PRPs.

\subsection{Bare PRPs are sensitive to obviation}

There is a phenomenon in French (and other languages) known as obviation which refers to the ban on coreference between a matrix and an embedded overt subject with some of the embedding verbs which select for the subjunctive mood in their complement (Ruwet 1984; Farkas 1992; Costantini 2005 among others). For instance (26a) is not good but (26b) is. The only thing that has changed though is the embedding verb: souhaiter cannot embed a finite clause whose subject is coreferential with the matrix subject whereas espérer can. (In what follows I say that espérer is -obviation whereas souhaiter is a +obviation verb.)

$$
\begin{aligned}
& \text { a. *Je souhaite que je joue demain. } \\
& \text { I sOUHAITER that I play.suBJ tomorrow } \\
& \text { 'Int. I want to play tomorrow.' } \\
& \text { b. J' espère que je jouerai demain. } \\
& \text { I hope that I play.FuT tomorrow } \\
& \text { 'I hope I will play tomorrow.' }
\end{aligned}
$$


Obviation has been given analyses which can be classified into two kinds: competition analyses and binding-theoretical analyses (see Costantini 2005 for a good summary). Competition analyses (Bouchard 1982; 1983; Farkas 1992; Schlenker 2005) argue that obviation follows from the competition between subjunctive and infinitive while binding theoretical analyses (Suñer 1986; Rizzi 1990; Avrutin \& Babyonyshev 1997) argue that the use of the subjunctive makes the binding domain bigger and obviation follows from principle B. Crucially, in both approaches, obviation relies on clausal properties that are represented in the syntax of the clause.

If embedded PRPs do involve a (sometimes elided) clause, we expect them to show the same sensitivity to obviation as full clauses do. On the other hand, if they behave like proforms, we should not see any effect. Notice how the clause-level proform le in (27) is not sensitive to obviation.

$$
\begin{aligned}
& \text { A: Est- ce que tu vas jouer demain ? } \\
& \text { it it that you go play tomorrow } \\
& \text { 'Are you going to play tomorrow?' }
\end{aligned}
$$

B1: Je le souhaite.

I it SOUHAITE

'I want to.'

B2: Je l' espère.

I it hope

'I hope so.'

Just like the embedded full clause in (28a), the embedded PRP produces unacceptability (28b) whereas the proform is perfectly acceptable (28c). This is expected if PRPs have a full clause at some level of representation.
$*\left[\right.$ subject $_{i} \ldots \mathrm{V}_{+o b v} \ldots$ subject $_{i}$
a. *Je ne sais pas si je viendrai demain mais je souhaite que
I neg know neg if I come.FUT tomorrow but I SOUHAITE that
je vienne
I come.subj
'Int. I don't know whether I'll be able to come tomorrow but I want to.'
b. *Je ne sais pas si je viendrai demain mais je souhaite que oui. I neg know neg if I come.FUT tomorrow but I SOUHAITE that yes
c. Je ne sais pas si je viendrai demain mais je le souhaite.
I neg know neg if I come.FUT tomorrow but $\mathrm{I}$ it SOUHAITE
'I don't know whether I'll come but I hope I will.'

Obviation in (28a/b) can be alleviated in two ways: if the subjects do not corefer (29) and if the embedding verb is -obviation (30). In both cases, PRP embedding is possible which is exactly what is predicted if bare PRPs in those examples have an elided full clause.

(29) No coreference: subject $_{i} \ldots \mathrm{V}_{+o b v} \ldots$ [ subject $_{j}$

a. Je ne sais pas si Tom viendra demain mais je souhaite qu'

I NEG know NEG if Tom come.FUT tomorrow but I wish that

il vienne.

he come.sUBJ

'I don't know whether Tom will come tomorrow but I hope he will.' 
b. Je ne sais pas si Tom viendra demain mais je souhaite que oui. I NEG know NEG if Tom come.FUT tomorrow but I wish that yes 'I don't know whether Tom will come tomorrow but I hope he will.'

c. Je ne sais pas si Tom viendra demain mais je le souhaite. I NEG know NEG if Tom come.FUT tomorrow but $I$ it wish 'I don't know whether Tom will come tomorrow but I hope he will.'

-obviation verb: $\left[\right.$ subject $_{i} \ldots \mathrm{V}_{-o b v} \ldots{\text { [ } \text { subject }_{i}}$

a. Je ne sais pas si je viendrai demain mais $j$ ' espère que je I NEG know NEG if I come.FUT tomorrow but I hope that I viendrai. come.fut 'I don't know whether I'll come tomorrow but I hope I will.'

b. Je ne sais pas si je viendrai demain mais $j$ ' espère que oui. I NEG know NEG if I come.FUT tomorrow but I hope that yes 'I don't know whether Tom will come tomorrow but I hope I will.'

c. Je ne sais pas si je viendrai demain mais je l' espère. I NEG know NEG if I come.FUT tomorrow but I it hope 'I don't know whether Tom will come tomorrow but I hope I will.'

Similar examples can be constructed with fragment PRPs: in (31a), the matrix and embedded subject are coreferential and this is disallowed by the embedding verb souhaiter since it is obviative. Example (31b) is better because no such coreference arises and example (31c) is also better because the embedding verb espérer does not disallow coreference between matrix and embedded subjects.

a. *Je ne sais pas si je les ai tous invités mais je souhaite I NEG know NEG if I them have all invited but I SOUHAITE que Marie oui. that Marie yes

'Int. I don't know whether I invited all of them but I hope I did invited MARIE.'

b. Je ne sais pas si Tom les a tous invités mais je souhaite I NEG know NEG if Tom them has all invited but I SOUHAITE que Marie oui. that Marie yes

'I don't know whether Tom invited all of them but I hope that he did invite MARIE.'

c. Je ne sais pas si je les ai tous invités mais $j$ ' espère que I NEG know NEG if I them have all invited but $I$ hope that Marie oui.

Marie yes

'I don't know whether I have invited them all but I hope to have invited Marie.'

The same pattern of (un)acceptability holds if the full clause to the right of PRPs is not elided.

a. *Je ne sais pas si je les ai tous invités mais je souhaite I NEG know NEG if I them have all invited but I SOUHAITE que Marie oui je l' aie invitée. that Marie yes I her have.suBJ invited 'Int. I don't know whether I invited all of them but I hope I did invite MARIE.' 
b. Je ne sais pas si Tom les a tous invités mais je souhaite I NEG know NEG if Tom them has all invited but I SOUHAITE que Marie oui il l' ait invitée. that Marie yes he her have.suBJ invited 'I don't know whether Tom invited all of them but I hope he did invite MARIE.'

c. Je ne sais pas si je les ai tous invités mais j' espère que I NEG know NEG if I them have all invited but $I$ hope that Marie oui je l' ai invitée. Marie yes I her have invited 'I don't know whether I have invited them all but I hope to have invited Marie.'

In section 3.1, we saw that PRPs are selected by attitude verbs that can embed finite clauses and I proposed that this follows if we assume that embedded PRPs are finite clauses (with an elided constituent). In this section, we further saw that if a PRP constituent indeed contains a elided clause, then obviation effects are predicted. Crucially, analyzing PRPs as pure proforms like le or cela makes false predictions in both respects. ${ }^{7,8}$

\footnotetext{
${ }^{7}$ Under the hypothesis that PRPs are sentence-level proforms, one might entertain that PRPs and e.g. cela are sentence-level proforms of different syntactic types such that only PRPs are embeddable with que. For instance, one might posit that PRPs are of syntactic type TP whereas cela/le is of type CP. This would be a weaker proform hypothesis. If this is the case, I assume they would show the same insensitivity to finiteness.

${ }^{8}$ So far we have not seen any effect of the shape of the antecedent (i.e. its syntax) on the felicity of an embedded PRP, all the contrasts we observed follow from restrictions on what the attitude verb can embed. Testing whether the shape of the antecedent of a PRP has an effect on the felicity of the PRP (e.g. by creating a clash between the shape of the antecedent and the selectional restriction of the attitude verb) yields data that are not easy to interpret. In fact, although there are interesting examples of clashes, I have not reached firm conclusions. For instance, Grevisse \& Goosse (2007) note that when the antecedent is an infinitive, pas is used rather than non. The two examples they give turn out to be confounded given the obviation facts observed above. Nevertheless, their observation seems to hold in examples like (i): the question in (i) is just an infinitival VP and answering with an embedded PRP is not felicitous (ia) whereas an answer with pas is good (ib). An embedded PRP response becomes acceptable if the question is finite (ic).
}

(i) a. \#Aller en pension ? Je crois que non.

go to boarding_school I think that no

b. Aller en pension? Je crois pas.

go to boarding_school I think not

'Go to boarding school? I don't think I will.'

c. Est -ce que je veux aller en pension? Je crois que non. is it that I want go to boarding_school I think that no 'Do I want to go to boarding school? I think that I don't want to.'

But in (ii) where the PRP non responds to an assertion, whether in a dialogue or not, the infinitival clause aller bien is the antecedent of non.

(ii) a. A: Elle prétend aller bien. she pretends go well

B: Moi je crois que non.

me I think that no

'A: She pretends that she is well. B: I think that she is not. (or B: I think that she does not pretend that ...)'

b. Elle prétend aller bien mais je crois que non.

she pretends go well but I think that no

'She pretends that she is well but I think that she is not. (*but I think that she does not pretend that ...)'

In conclusion, it does not seem to be the case that an infinitival clause can never be the antecedent of a PRP. To explain the difference in acceptability between (ia)-where the infinitival cannot be the antecedent of the PRP-and (iia)—where it can-, an anonymous reviewer suggests that the crucial difference is that the infinitival in (iia) denotes a full proposition (with world and time indices) whereas the infinitival in (ia) does not. The idea being that clauses containing bare PRPs must be anaphoric to full propositions, nothing less. This is an interesting idea, especially as (ia) becomes perfectly acceptable once a full clause follows the PRP. 


\subsection{Bare PRPs are sensitive to antilogophoricity}

We can use antilogophoric effects to diagnose the presence of an elided constituent. According to Dubinsky \& Hamilton (1998), epithets are antilogophoric pronouns, i.e. DPs subject both to principle B of the binding theory and the antilogophoric constraint in (33).

Antilogophoricity constraint for epithets (Dubinsky \& Hamilton 1998)

An epithet must not have as its antecedent the perspective bearer. ${ }^{9}$

In (34A), a question is asked with the epithet cet imbécile 'this idiot' anaphoric to an individual called Jean. In the (B1) and (B2) responses to this question, the attitude holder/perspective bearer ${ }^{10} \mathrm{~B} 1$ is unacceptable because the epithet cet imbécile is preceded by the co-indexed perspective bearer Jean, however notice that (B2), where the DP-level pronoun le is used, is completely acceptable. (The phrase c'est évident 'it is obvious' is peripheral and only serves to make the sentence more natural given that it repeats almost word-for-word the formulation of the question.)

Context: Adrian and Bart have been talking about Jean, whom they do not like.

A: Est- ce que tu crois que Marie et Alex aiment cet imbécile ${ }_{i}$ ? is it that you believe that Marie and Alex love this idiot 'Do you think that Marie and Alex love this idiot?'

B1: ' $\operatorname{Jean}_{i}$ pense qu' ells aiment cet imbécile ${ }_{i}$, c' est évident. Jean thinks that they love this idiot it is obvious

B2: Jean ${ }_{i}$ pense qu' ells $l_{i}^{\prime}$ aiment, c' est évident. Jean thinks that they him love it is obvious 'Jean thinks that they love him, it's obvious.'

In a PRP response to (34A), if the embedded bare PRP involves ellipsis, we expect the response to be as unacceptable as (34B1), if however the embedded PRP is a proform, we expect the response to be as acceptable as (34B2). As the response in (35B3/B4) shows, the ellipsis hypothesis makes the right prediction: embedded bare PRPs are sensitive to antilogophoricity. Ways to make this response better are using the clauselevel proform le as in (35B5) or making the perspective bearer not the antecedent of the epithet as in (35B6).

$$
\begin{aligned}
& \text { B3: 'Jean }{ }_{i} \text { pense que oui, c' est évident. } \\
& \text { Jean thinks that yes it is obvious } \\
& \text { B4: 'Jean }{ }_{i} \text { pense que Marie oui, c' est évident. } \\
& \text { Jean thinks that Marie yes it is obvious } \\
& \text { B5: Jean le pense, c' est évident. } \\
& \text { Jean it thinks it is obvious } \\
& \text { 'Jean thinks so, it's obvious.' }
\end{aligned}
$$

\footnotetext{
(iii) Aller en pension ? Je crois que non, je veux pas. go to boarding_school I think that no I want NEG 'Go to boarding school? I don't think I want to.'
}

I leave an examination of this idea for further research.

${ }^{9}$ The perspective bearer is an individual from whose perspective the attributive content of the epithet is evaluated (Dubinsky \& Hamilton 1998).

${ }^{10}$ As noted by Dubinsky \& Hamilton (1998), the subject of psychological verbs and verbs of saying typically has perspective over the sentential complement. 
B6: Je ${ }_{j}$ pense que oui, c' est évident.

I think that yes it is obvious

'I think that they do, it's obvious.'

Embedded bare PRPs are sensitive to antilogophoricity just like their clause-peripheral (by hypothesis non-elided) counterparts (36).

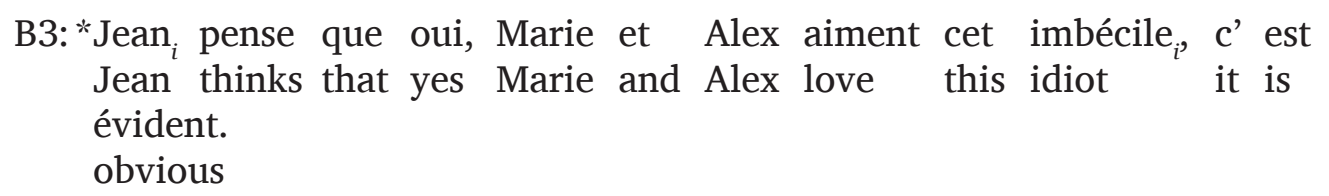

B3: * Jean ${ }_{i}$ pense que oui, Marie et Alex aiment cet imbécile, c' est Jean thinks that yes Marie and Alex love this idiot it is évident. obvious

B4: *Jean ${ }_{i}$ pense que Marie $_{j}$ oui, elle ${ }_{j}$ aime cet imbécile ${ }_{i}$, c' est évident. Jean thinks that Marie yes she loves this idiot it is obvious

B6: $\mathrm{Je}_{j}$ pense que oui, Marie et Alex aiment cet imbécile, ${ }_{i}$ c' est évident. I think that yes Marie and Alex love this idiot it is obvious 'I think that Marie and Alex love this idiot it is obvious.'

Thus the ellipsis hypothesis in (11) makes four predictions that an ellipsis-based analysis can easily handle:

i. PRPs can only appear where finite clauses can (unlike proforms)

ii. PRPs are sensitive to obviation (unlike proforms)

iii. PRPs are sensitive to antilogophoricity (unlike proforms)

In the next section, I spell out my analytical assumptions concerning the structure of PRPs and then show that embedded PRPs in French always come with a clause - covert or overt - which is identical to the PRP antecedent.

\section{Analytical proposal \\ 4.1 Analytical assumptions}

Following Kramer \& Rawlins (2010); Authier (2013); Roelofsen \& Farkas (2014); Pasquereau (2018; 2020) among others, I take PRPs in French to be the spell out of a feature-bearing head-Authier (2013) calls it Fin, Roelofsen \& Farkas (2014) call it Pol, Kramer \& Rawlins (2010) call it $\Sigma$-which takes a full clause as its complement (37). I assume that the basic structure of a clause containing an embedded PRP is as in (37). Depending on what the value of the features on Pol is (see Roelofsen \& Farkas (2014) or Pasquereau 2020), it is realized as oui, non, or si.

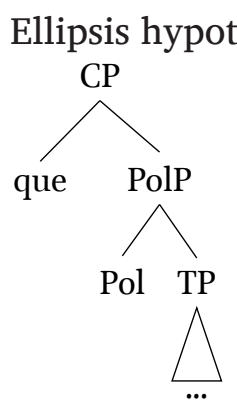

Kramer \& Rawlins (2010; 2011) and Holmberg (2013) assume that English PRPs are adverbs in the specifier of a head ( $\Sigma$ for Kramer and Rawlins, Foc for Holmberg). As Kramer \& Rawlins (2011) point out, analyzing French PRPs as being hosted in a head (as opposed to its specifier) correctly predicts that they can be embedded. As far as I can 
tell, Pol (following Roelofsen \& Farkas 2014) and $\Sigma$ (following Kramer \& Rawlins 2010) are notational variants which refer to the same object. Authier (2013) assumes that PRPs are hosted in Fin, one of the heads in the articulated Rizzian view of the C domain (Rizzi 1997; 2001) where C corresponds to the head hierarchy in (38) (from Authier (2013: 353)). Authier's proposal has the important advantage of proposing a way to derive the restrictions on PRP embedding alluded to in section 2.3. I continue to use the structure in (37) as the point of this paper is not to argue for which specific head or projection hosts PRPs.

$$
\text { Force }>\text { (Top) }>\text { Int }>\text { (Top) }>\text { Foc }>\text { (Top) }>\text { Fin }>\text { T }
$$

The prejacent TP can optionally be elided under semantic identity with some constituent in the preceding question. I call this constituent "the antecedent". Thus what I have called until now bare and clause-peripheral PRPs are in fact two realizations of the same underlying structure. I use Merchant (2001)'s e-givenness notion of semantic identity (39).

\section{Definition of e-givenness (Merchant 2001)}

An expression $\in$ is e-given iff $\in$ has a salient antecedent A such that $\llbracket A \rrbracket$ entails F-clo $(\epsilon)$ and $\llbracket \in \rrbracket$ entails F-clos (A)

\section{Definition of (existential) F-closure of $\mathcal{E}$ (Schwarzschild 1999)}

F-clo $(\epsilon)=\llbracket$ the result of replacing F-marked phrases in $\in$ with variables and existentially closing all variables》

Moreover, following Merchant (2005); Authier (2013), I assume that polarity fragments come to be via overt movement of the fragment out of TP followed by TP ellipsis as shown in (41).

$$
\begin{aligned}
& \text { A: Est -ce qu' ils sont arrives ? } \\
& \text { is it that they are arrived } \\
& \text { 'Have they arrived?' } \\
& \text { B: Je crois que }\left[{ }_{\text {PolP }} \text { Jean }_{i} \text { oui } \mathrm{E}_{\mathrm{TP}} \mathrm{t}_{i} \text {-est arrivé }\right] \text { is arrived } \\
& \text { I think that Jean yes } \\
& \text { 'I think that Jean has arrived.' }
\end{aligned}
$$

The reader might wonder how the e-givenness condition on ellipsis can handle cases where a PRP reverses the polarity of the antecedent. The answer to this question lies in the analysis of what meaning(s) PRPs encode-parameter 2 in (5). Though the goal of this paper is purely to argue for an ellipsis-based approach and is thus in principle compatible with any approach to parameter 2 that is based on ellipsis (Kramer \& Rawlins 2010; 2011; Authier 2013; Holmberg 2013; Roelofsen \& Farkas 2014; Pasquereau 2020), answering this question requires that I make explicit how at least one of these accounts extends to the structure I defend, e.g. Holmberg (2013)'s account of (matrix) English PRPs.

In the account in Holmberg (2013), English yes/no are assumed to be adverbs in [Spec, Foc]. In my extension of his account to French here I will assume that they are Pol heads. This change being made, the account in Holmberg (2013: 36) can now be straightforwardly extended to French embedded PRPs. Accordingly, French embedded PRPs are heads that assign positive and negative values respectively to the polarity head $\Sigma$ in their optionally elided TP complement. The $\Sigma$ head contains a polarity variable ranging over three values: affirmative $[+]$, negative $[-]$, and open $[ \pm]$, i.e. neither positive nor negative. Indeed, according to Holmberg (2013), positive polar questions have open polarity. The previous example thus has the syntax in (42). 
A: Est -ce qu' ils $\Sigma_{ \pm}$sont arrivés ? is it that they are arrived 'Have they arrived?'

B: Je crois que $\left[_{\text {PolP }}\right.$ Jean $_{i}$ oui ${ }_{+} t_{\mathrm{PP}}-t_{i} \Sigma_{+}$estarrivé $]$. I think that Jean yes is arrived 'I think that Jean has arrived.'

The idea is that, just as in other forms of ellipsis, identity is checked prior to the assignment of values to (polarity) variables, i.e. to $\Sigma$ (Holmberg 2013: 37, ex. 21): both the TP in the question (42A) and in the answer (42B) are e-given. In a negative answer, non assigns a negative value to $\Sigma$ (43): here, too, both the TP in the question (43A) and in the answer (43B) are e-given.

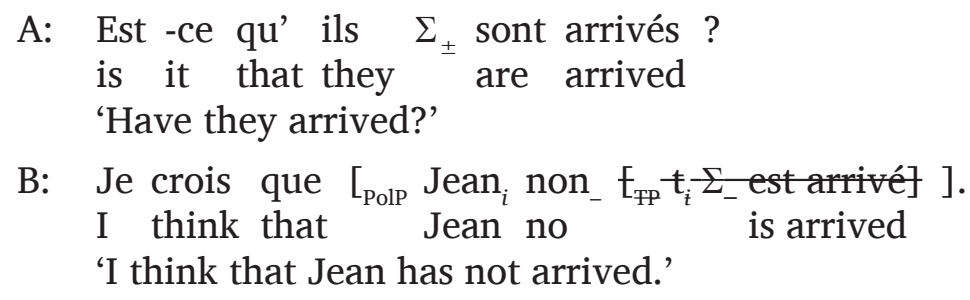

Once again, I do not commit to any particular analysis of what the meaning of PRPs is in this paper. ${ }^{11} \mathrm{My}$ only purpose here is to show that ellipsis-based analyses are compatible with the type of structure I argue for. In all the examples considered so far, and more 11 This is because this a very complex issue that requires to be the center of its own paper. As an anonymous
reviewer points out, approaches like my extension of Holmberg (2013)'s account that allow PRPs to seman-
tically encode positive or negative polarity make false predictions: e.g. the exchange in (i) should not be
acceptable, contrary to fact.

(i) A: Il est pas fûté, celui-là. he is NEG shrewd, this_one 'That guy's not very smart.'

B: Ah ça oui, il est pas fûté. well this yes he is NEG shrewd 'Yeah, he's not.'

But likewise, approaches that take the view that PRPs merely reflects the polarity of their complement TP, like Authier (2013)'s, run into other issues: e.g. they wrongly predict that both non answers in (ii) and (iii) can convey agreement.

(ii) A: Est -ce que Marie n' a pas pris de gâteau du tout ? is it that Marie NEG has NEG taken of cake at all 'Has Marie not had any cake at all?'

B: Je crois que non.

I think that no

'I think that she has not.'

(iii) Context: One piece of cake remains. It's odd, I had counted exactly as many pieces as there were people.
A: Est -ce quelqu'un n' a pas pris de gâteau du tout ?
is it that someone NEG has NEG taken of cake at all 'Has someone not had any cake at all?'
B: Je crois que non.
I think that no
'I think that everyone has had cake.'

Pasquereau (2020) takes up these issues as its main goal and develops a proposal for parameter 2. It would however take too much space here to develop the proposal. 
specifically in all the examples where a PRP was followed by an overt clause, that overt clause was semantically identical to, i.e. e-given with respect to its antecedent. In the next section, I consider cases where a PRP is followed with a clause which is not e-given. I provide arguments that, even in these cases, French embedded PRPs always come with a prejacent-overt or covert-that is identical to their antecedent.

\subsection{There is always an identical prejacent, whether it is overt or not}

Consider the question in (44A) and three possible responses: B1 contains an embedded bare PRP, and B2, B3 contain an embedded clause-peripheral PRP, i.e. their PRP is followed by a full clause. I only consider PRPs followed by TPs, and not e.g. PRPs followed by CPs (for ellipsis diagnostics involving the coordination of a bare PRP and a CP, see Authier 2013). Responses B1 and B2 have the same truth-conditions; this is expected under the ellipsis account, B1 is derived from B2 via ellipsis of the full clause to its right since it is e-given with respect to its antecedent il est coupable 'he is guilty' in the question. So far, I have only considered such cases: cases where a PRP is either bare or followed by a clause which is semantically identical to a clause in the preceding discourse, i.e. its antecedent (in my examples the clause embedded under est-ce que in the question). But PRPs can be followed by a range of clauses that are often not semantically identical to a clause in the preceding discourse like B3: clearly B1 and B3 do not have the same truthconditions.
A: Est -ce que tu crois qu' il est coupable ? is it that you think that he is guilty 'Do you think he's guilty?'

B1: Je crois que oui. I believe that yes 'I believe he is.'

B2: Je crois que oui, il est coupable. I believe that yes he is guilty 'I believe that he is guilty.'

B3: Je crois que oui, il s' est enfui en courant. I believe that yes he fled in running 'I believe he is, he ran away.'

Following the line of reasoning in Laka (1990), the question I would like to explore is whether the responses in B2 and B3 have the same structure. That is, in response to A, is the structural relationship between the PRP oui and the full clause in B2 the same as the structural relationship between the PRP oui and the full clause in B3?

Like Laka (1990) for matrix PRPs in English, I argue that (44B2) and (44B3) do not have the same underlying structure. More specifically, I argue that (44B3) contains a PRP prejacent, i.e. an elided clause that is e-given with respect to its antecedent in A as schematized in (46A). Thus a clause-peripheral PRP with an e-given overt clause has the structure in (45B1) where the e-given clause is the complement of the Polarity head/PRP. However, a non-elidable, non-e-given coda has the underlying structure in (45B2), where two clauses are juxtaposed: one involving a PRP with its elided prejacent and another one that elaborates on the answer.

A: Est -ce que tu crois qu' il est coupable ? is it that you think that he is guilty 'Do you think he's guilty?' 
B1: Je crois que $\left[_{\text {PolP }}\right.$ oui, $\left[_{\mathrm{TP}}\right.$ il est coupable $]$ ].

I believe that yes he is guilty

'I believe he is.'

B2: Je crois que $\left[_{\mathrm{PolP}}\right.$ oui, $\mathrm{t}_{\mathrm{TP}}$ il est coupable $]\left[_{\mathrm{TP}}\right.$ il s' est enfui en courant ]. I believe that yes he is guilty he fled in running 'I believe he is, he ran away.'

In other words, the claim I entertain and defend in this paper is that a PRP always comes with a (covert or overt) full clause that is identical to its antecedent, the prejacent; this is the "heterogeneous" view.

The alternative hypothesis would be that "what you see is what you get" and that (44B2) and (44B3) have the same structure: in both (44B2) and (44B3), the full clause is the complement of the PRP oui. According to this view, in response to a given question, whether a sentence following a PRP can potentially be elided or not - whether it meets the identity condition on ellipsis or not - does not impact their structure, i.e. the PRP responses in (46B1) and (46B2) have the same structure; this is the "uniform" view.

A: Est -ce que tu crois qu' il est coupable ?

is it that you think that he is guilty

'Do you think he's guilty?'

B1: Je crois que $\left[_{\mathrm{PolP}}\right.$ oui, $\left[_{\mathrm{TP}}\right.$ il est coupable $]$ ]. I believe that yes he is guilty

'I believe he is.'

B2: Je crois que $\left[_{\mathrm{PolP}}\right.$ oui, $\left[_{\mathrm{TP}}\right.$ il s' est enfui en courant $]$ ].

I believe that yes he fled in running

'I believe he is, he ran away.'

The two hypotheses under consideration try to relate bare PRPs to clause-peripheral PRPs. On the uniform view, a PRP and the full clause to its right are always part of the same clause, whereas on the heterogeneous view, the structure of a PRP followed by a full clause depends on whether the full clause is e-given with respect to a constituent in the preceding discourse. If the clause is not e-given with respect to the antecedent, it is two clauses, if the clause is identical to the antecedent (abstracting away from polarity), it is one clause. These differences and similarities are summarized in Table $\mathbf{1 .}$

First, I use subjunctive assignment to show that given a specific question, e-given and non-e-given clauses have different syntactic statuses: they do not have the same structure. I propose following Laka (1990) that this is because non-e-given clauses follow an elided e-given prejacent. Second, I provide evidence that certain patterns follow if we assume that non-e-given codas are preceded by an e-given elided prejacent.

\subsubsection{Subjunctive assignment across clause-peripheral PRP}

Among the attitude verbs that select for a finite clause in French, some verbs select for a clause whose main predicate is in the subjunctive mood, sembler 'seem' is a verb which allows both indicative (47B1) and, crucially, subjunctive (47B2).

Table 1: Does the sequence "PRP clause" always come with an e-given (covert or overt) clause?

\begin{tabular}{|l|l|l|}
\hline & no/uniform view & yes/heterogeneous view \\
\hline clause is e-given & \multirow{2}{*}{ no elided clause } & no elided clause \\
\cline { 1 - 1 } clause is not e-given & & elided e-given clause \\
\hline
\end{tabular}


A: Est- ce qu' ils ont acheté ce livre ? is it that they have bought this book 'Have they bought this book?'

B1: Il semble que oui, ils l' ont acheté. it seems that yes they it have bought 'It would appear they did.'

B2: Il semble que oui, ils l' aient acheté. it seems that yes they it have.SUBJ bought 'It seems that yes they bought it.'

But if the clause that follows the PRP is not e-given as in the dialogue in (48), subjunctive assignment is no longer possible (B1), only the indicative is possible (B2).

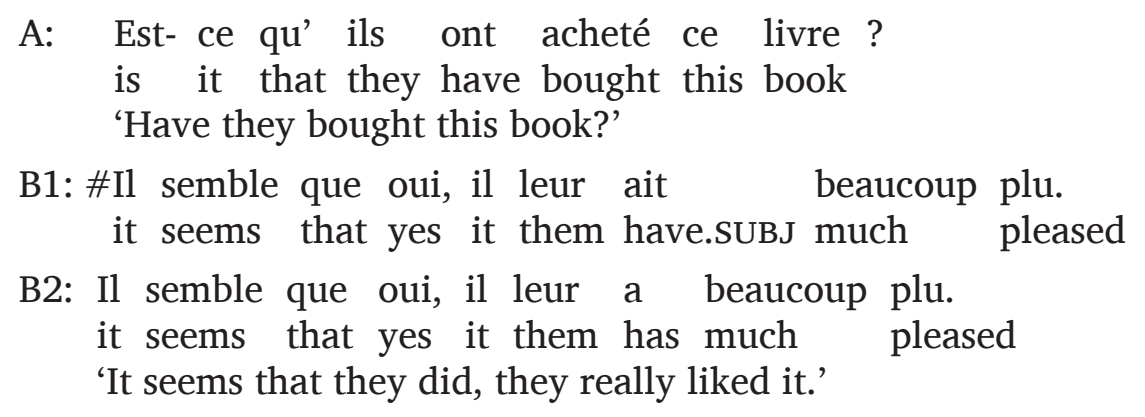

This asymmetry tells us that non-e-given clauses have a different status from e-given clauses with respect to the PRP they follow. Thus, this constitutes an argument to dismiss the uniform hypothesis according to which e-given and non-e-given clauses stand in the same syntactic relation to a PRP.

In what follows, I argue that the difference in acceptability between (48B1) and (47B1) reflects a structural difference: the clause in (47B1) is e-given and is syntactically the complement/prejacent of Pol as represented in (49B1), but in (48B2) the clause is not e-given and just follows the elided e-given prejacent as represented in (49B2). The reason for the unacceptability of (49B2), I argue below, is that subjunctive assignment is not possible across another clause. (Note that for now I do not commit to whether the second clause is also embedded under the subjunctive-assigning verb, or whether it is its own sentence).

$$
\begin{aligned}
& \text { A: Est- ce qu' ils ont acheté ce livre ? } \\
& \text { is it that they have bought this book } \\
& \text { 'Have they bought this book?' } \\
& \text { B1: Il semble que }\left[_ { \text { PolP } } \text { oui, } \left[_{\mathrm{TP}}\right.\right. \text { ils l' aient acheté ]]. } \\
& \text { it seems that yes they it have.SUBJ bought } \\
& \text { 'It would appear they did. } \\
& \text { B2: "Il semble que }\left[_ { \mathrm { PolP } } \text { oui, } [ _ { \mathrm { TP } } \text { ils } 1 \text { ' aient acheté } ] \left[_{\mathrm{TP}}\right.\right. \text { il leur } \\
& \text { it seems that yes they it have.SUBJ bought it them } \\
& \text { ait beaucoup plu ]. } \\
& \text { have.SUBJ much pleased } \\
& \text { 'Int. It seems that they did, they really liked it.' }
\end{aligned}
$$

In this part, I show that subjunctive can only be assigned to the main verb of a clause which is adjacent to the subjunctive-assigning verb. Thus, I will compare such a structure (50a) with a structure like (50b) where the subjunctive-assigning verb is followed by two clauses. 
(The structure in 50b could potentially be as in (50bi)—with both clauses juxtaposed and embedded under the subjunctive-assigning verb-, or it could be as in (50bii) with only one embedded clause, clause 2 being in a separate sentence. I discuss these two possibilities further on.)

a. V que [ clause ]

b. V que [ clause 1 ] [ clause 2 ]

i. One (embedded) sentence: $\mathrm{V}$ que [ [ clause 1 ] [ clause 2 ] ]

ii. Two sentences: $\mathrm{V}$ que [ clause 1 ]. [ clause 2 ]

As the acceptability of (47B1) confirms, the subjunctive-assigning verb sembler can assign subjunctive to a directly adjacent clause (configuration 50a). We now need to examine in configuration (50b) whether subjunctive assignment is possible to clause 2 . Two structures possibly exemplify this configuration. Either clause 1 and clause 2 are part of the same sentence but in different juxtaposed clauses in the scope of the attitude verb as illustrated in (50bi) or clause 1 and clause 2 are each part of a different sentence - clause 1 is embedded under $\mathrm{V}$ whereas clause 2 is a matrix sentence - as illustrated in (50bii). I show that whatever sub-configuration is involved, we can conclude that subjunctive assignment is not possible across a clause.

One reason to think that a structure such as the one-sentence option of configuration (50bi) is possible is example (51B1): if the coda elle fait de la trompette were not in the scope of penser 'think', the resulting sentence would be contradictory as (51B2) shows. (The sentence with its elided prejacent realized overtly in (51B3) has the same judgment.)

A: Est -ce que Marie fait du piano ?

is it that Marie does of.the piano

'Does Marie play piano?'

B1: Tom pense que non, elle fait de la trompette mais moi je ne Tom thinks that no she does of the trumpet but me I NEG crois pas qu' elle sache jouer de la trompette.

believe NEG that she know.SUBJ play of the trumpet

'Tom thinks that she does not, that she plays trumpet but I don't believe that she knows how to play trumpet.'

B2: \#Elle fait de la trompette mais moi je ne crois pas qu' elle she does of the trumpet but me I NEG believe NEG that she sache jouer de la trompette.

know.SUBJ play of the trumpet

'She plays trumpet but I don't believe that she knows how to play trumpet.'

B3: Tom pense que non, elle ne fait pas de piano, elle fait de Tom thinks that no she NEG do.SUBJ NEG of piano she does of la trompette, mais moi je ne crois pas qu' elle sache the trumpet but me I NEG believe NEG that she know.SUBJ jouer de la trompette. play of the trumpet 'Tom thinks that she does not, that she plays trumpet but I don't believe that she knows how to play trumpet.'

A similar response to (51A) can be given with the structure in (52B1) and its non-elided counterpart in (52B2). 
B1: D'après Tom, il semble que non, elle fait de la trompette mais according.to Tom it seems that no she does of the trumpet but moi je ne crois pas qu' elle sache jouer de la trompette. me I NEG believe NEG that she know.SUBJ play of the trumpet 'According to Tom it seems that she does not, she plays trumpet but I don't believe that she knows how to play trumpet.'

B2: D'après Tom, il semble que non, elle ne fasse pas de piano, according.to Tom it seems that no she NEG do.SUBJ NEG of piano elle fait de la trompette, mais moi je ne crois pas qu' elle she does of the trumpet but me I NEG believe NEG that she sache jouer de la trompette. know.SUBJ play of the trumpet 'According to Tom it seems that she does not, she plays trumpet but I don't believe that she knows how to play trumpet.'

This response however becomes unacceptable if the non-e-given coda elle fait de la trompette 'she plays trumpet' is in the subjunctive mood (53B1). This sentence with its elided prejacent realized overtly in (53B2) has the same judgment.

A: Est -ce que Marie fait du piano?

is it that Marie does of.the piano

'Does Marie play piano?'

B3: \#D'après Tom, il semble que non, elle fasse de la trompette according.to Tom it seems that no she do.SUBJ of the trumpet mais moi je ne crois pas qu' elle sache jouer de la but me I NEG believe NEG that she know.SUBJ play of the trompette.

trumpet

'Int. Tom thinks that she does not, that she plays trumpet but I don't believe that she knows how to play trumpet.'

B4:\#D'après Tom, il semble que non, elle ne fasse pas de piano, according.to Tom it seems that no she NEG do.SUBJ NEG of piano elle fasse de la trompette, mais moi je ne crois pas qu' she do.SUBJ of the trumpet but me I NEG believe NEG that elle sache jouer de la trompette.

she know.SUBJ play of the trumpet

'Tom thinks that she does not, that she plays trumpet but I don't believe that she knows how to play trumpet.'

In conclusion, even if two juxtaposed clauses are embedded under a subjunctive-assigning verb (configuration (50bi)), the second clause cannot receive subjunctive assignment. Next, I show that, as may be expected, if the second clause is not embedded under a subjunctive-assigning verb (configuration (50bii)), because this second clause is in another matrix-level sentence, it cannot receive subjunctive from that verb either. In (54), response (B1) becomes unacceptable if the clause following the PRP is in a different sentence from the matrix subjunctive-assigning verb (B2). To make clear that there are two sentences, I separate them with en fait c'est sûr 'in fact it's sure'. This example becomes acceptable again if the verb is not in the subjunctive (54B3).

A: Est- ce qu' ils ont acheté ce livre ?

is it that they have bought this book

'Have they bought this book?' 
B1: Il semble que oui, ils l' aient acheté. it seems that yes they it have.SUBJ bought 'It would appear they did, buy it, that is.'

B2: *Il semble que oui ... en fait c' est sûr ... Ils l' aient acheté. it seems that yes in fact it is sure they it have.suBJ bought

B3: Il semble que oui ... en fait c' est sûr ... Ils l' ont acheté. it seems that yes in fact it is sure they it have bought 'It would appear they did ... in fact, I'm positive ... They did.'

We can thus safely conclude that subjunctive assignment is not possible across a clause to a second clause - whether the latter is embedded under the subjunctive-assigning verb or not.

I take those observations to indicate that the problem with (48B1) repeated in (55B2) is indeed that the non-e-given clause il leur ait beaucoup plu 'they liked it a lot' is preceded by a full clause, the PRP prejacent, which is e-given and has been elided.

A: Est- ce qu' ils ont acheté ce livre ?

is it that they have bought this book 'Have they bought this book?'

B1: Il semble que $\left[_{\text {PolP }}\right.$ oui, $\left[_{\text {TP }}\right.$ ils l' aient acheté $]$ ]. it seems that yes they it have.SUBJ bought

'It would appear they did.'

B2: \#Il semble que $\left[_{\mathrm{PolP}}\right.$ oui, $\left[_{\mathrm{TP}}\right.$ ils 1 ' aient acheté $]\left[_{\mathrm{TP}}\right.$ il leur it seems that yes they it have.SUBJ bought it them ait beaucoup plu ].

have.SUBJ much pleased

In what follows, I provide further evidence that the acceptability difference between (55B1) and (55B2) is caused by the fact that embedded PRPs in French always come with a clause that is contextually e-given.

\subsubsection{Overt realization of elided material}

The clause in (56B2) is the realization of the elided prejacent in (56B1). It can be elided because it is e-given with respect to the clause in the scope of the question operator in $\mathrm{A}$.

A: Est -ce que Marie fait du piano ?

is it that Marie does of.the piano

'Does Marie play piano?'

B1: Je pense que non.

I think that no

'I don't think she does.'

B2: Je pense que non, elle ne fait pas de piano.

I think that no she NEG does NEG of.the piano

'I think that no, she does not play piano.'

If according to the heterogeneous syntax hypothesis, a PRP is always followed by a optionally-elided prejacent, the structure of (57B3) in response to (56A) is as in (57a).

(57) B3: Je pense que non, elle fait de la guitare.

I think that no she does of the guitar

'I don't think she does, she plays guitar.' 
a. Ellipsis

Je pense que non felle ne fait pas de piano\}, elle fait de la guitare.

b. No-ellipsis

Je pense que non, elle fait de la guitare.

This correctly predicts that the elided e-given prejacent can be pronounced (58).

B4: Je pense que non elle ne fait pas de piano, elle fait de la guitare. I think that no she NEG does NEG of piano she does of the guitar 'I don't think she plays piano, she plays guitar.'

Remember that under the ellipsis analysis of bare PRPs, polarity fragments result from movement of a topic out of the elided constituent. If, consistent with the heterogeneous coda syntax hypothesis, a PRP construction containing a coda non-identical to the antecedent is underlyingly composed of a bare PRP with its elided prejacent plus the coda, then it should be able to topicalize from it. This is indeed attested (59B1) just as is the case when the e-given prejacent is pronounced.

$$
\begin{aligned}
& \text { A: Est -ce que Marie fait du piano ? } \\
& \text { is it that Marie does of.the piano } \\
& \text { 'Does Marie play piano?' }
\end{aligned}
$$

B1: Je crains que du piano non, elle fait de la guitare. I fear that of.the piano no she does of the guitar 'I fear that piano she does not play, she plays guitar.'

B2: Je crains que du piano non, elle n' en fasse pas, elle fait I fear that of.the piano no she NEG of.it do.SUBJ NEG she does de la guitare. of the guitar 'I fear that piano she does not play, she plays guitar.'

Thus the heterogeneous coda syntax hypothesis makes two attested predictions that are not compatible with the uniform coda syntax view.

To recapitulate, I have argued that a PRP always comes with a clause that is e-given, a prejacent, which can be overt or covert. Cases where a non-e-given clause (overtly) follows a PRP are underlying composed of a PRP with an elided e-given prejacent, followed by the overt non-e-given clause. The non-e-given clause can be juxtaposed to the PolP but does not have to (60).
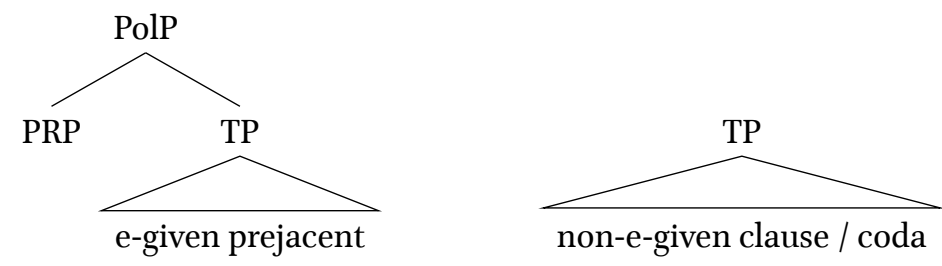

\section{An unexplained contrast for ellipsis}

So far, we have only seen cases of optional ellipsis: if the TP complement of Pol is e-given, TP can optionally be elided. However coda ellipsis is not always optional. A particularly hard problem for an ellipsis approach is that sometimes deletion is obligatory, as an anonymous reviewer points out for English PRPs. This is the case for French embedded PRPs 
too. The problem is that although bare PRPs can be embedded under si in the antecedent of a conditional, they cannot be followed by an overt prejacent or coda (61).

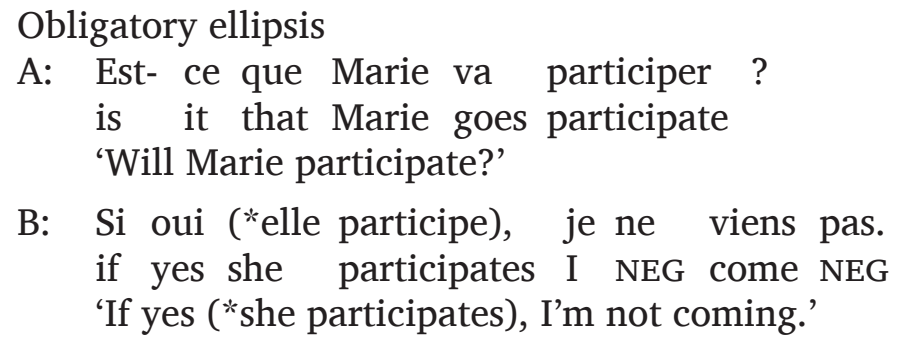

Although Krifka (2013)'s proform account can handle that contrast, we saw in sections 3 and 4 that it makes wrong predictions for embedding overall. Though I do not have a worked-out explanation for this contrast, I do not think it necessarily argues against the ellipsis analysis just yet. To see this, I would like to comment on a few assumptions I have been making throughout.

First, I have assumed that if embedded PRPs involve ellipsis, then at least some nonembedded PRPs involve ellipsis as well, and in fact I have been assuming that they have the same syntactic structure (modulo the addition of the speech act layer). This leaves open the possibility that some matrix PRPs might be different objects than embedded PRPs and the matrix PRPs that have the same syntax as embedded PRPs. Second, I have assumed that embedding under the conditional complementizer si and embedding under que are similar embedding environments. This is also something that could be explored, after all, although English disallows the sequence that yes/no in e.g. I think that yes/no, it does allow if yes/no. Thus it could be that the PRPs found in the antecedent of conditionals are more similar to the subset of matrix PRPs that do not involve ellipsis.

Third, I have not committed to any particular semantics of PRPs (question 2 in (5)), assuming that, the syntax of embedded bare and clause-peripheral PRPs being the same, PRPs always make the exact same semantic contribution and compose in the exact same way whether they are followed by an overt clause or not. But this assumption can be questioned in light of proposals that certain phrases can make a semantic contribution on one or another dimension of meaning, e.g. work on conventional implicatures (Potts 2005). Under such a line of explanation, one might consider whether the contrast in (61) could be due to a clash between the semantic contribution of clause-peripheral oui and that of the antecedent of the conditional.

Thus, the contrast in (61) remains an unexplained puzzle for the ellipsis account. Further work will show whether it really is a problem or whether it reveals a further property of PRPs.

\section{Conclusion}

This paper has presented new arguments made available by embedding that embedded PRPs in French are remnants of ellipsis and not proforms. Unlike other sentential proforms in French, PRPs on their own only replace finite clauses, are sensitive to obviation and to antilogophoricity. Finally assuming that PRPs on their own actually involve an elided clause makes it possible to derive that PRPs in French always come with a prejacent that is e-given, and therefore not all clauses following a PRP stand in a complement relationship with them. Rather, as first argued in Laka (1990), some responses containing a PRP and a full clause are monoclausal and some are biclausal, depending on whether the full clause is given in the previous discourse or not. As we saw in section 2.3, we can explain that the meaning of embedded PRP is a proper subset of the meaning of matrix PRP by 
extending Wiltschko's proposal for English PRPs as follows: French matrix and embedded PRPs have the same syntax (i.e. PRPs spell out a head which takes an elidable TP as their complement); PRPs can be embedded under a speech act layer, which gives PRPs their (dis)agreement meaning. I propose that the speech act layer cannot be embedded and this is why PRPs in embedded environments only have a proper subset of the meaning of matrix PRPs. Crucially though, it follows that if embedded PRPs involve ellipsis, then under this analysis, at least some matrix PRPs must involve ellipsis as well.

\section{Abbreviations}

COND $=$ conditionnel, FUT $=$ future, $\mathrm{INF}=$ infinitive, $\mathrm{NEG}=$ negation, $\mathrm{POS}=$ positive, $\mathrm{PTCP}=$ participle, $\mathrm{REFL}=$ reflexive, $\mathrm{REV}=$ reversal, $\mathrm{SUBJ}=$ subjunctive

\section{Acknowledgements}

I would like to thank Rajesh Bhatt and Vincent Homer for discussion and comments on several drafts of this paper, the speakers of French I consulted from the Nantes area (France), Laurence Pasquereau, and Georgia Sgourou. I also received valuable feedback from four anonymous reviewers, whose efforts led to substantial improvements in the text.

\section{Funding Information}

This work has been partly funded by the Arts \& Humanities Research Council (UK; grant AH/P002471/1), whose support is gratefully acknowledged.

\section{Competing Interests}

The author has no competing interests to declare.

\section{References}

Authier, Jean Marc. 2013. Phase-edge features and the syntax of polarity particles. Linguistic Inquiry 44(3). 345-389. DOI: https://doi.org/10.1162/LING_a_00132

Avrutin, Sergey \& Maria Babyonyshev. 1997. Obviation in subjunctive clauses and Agr: evidence from Russian. Natural Language \& Linguistic Theory 15(2). 229-262. DOI: https://doi.org/10.1023/A:1005732301928

Bouchard, Denis. 1982. On the content of empty categories. Cambridge, MA: Massachusetts Institute of Technology dissertation. DOI: https://doi.org/10.1515/9783110850000

Bouchard, Denis. 1983. The avoid pronoun principle and the elsewhere principle. In Peter Sells \& Charles Jones (eds.), Proceedings of the North Eastern Linguistics Society 13. 29-36. Amherst, MA: GLSA.

Cecchetto, Carlo. 1999. A comparative analysis of left and right dislocation in Romance. Studia Linguistica 53(1). 40-67. DOI: https://doi.org/10.1111/1467-9582.00039

Cohen, Marcel. 1952. Emplois nouveaux de oui et non en français. Bulletin de la Société de Linguistique de Paris 48. 40-51.

Costantini, Francesco. 2005. On obviation in subjunctive clauses: the state of the art. Annali di Ca'Foscari: Rivista della Facoltà di Lingue e Letterature Straniere dell'Università Ca'Foscari di Venezia 44(1-2). 97-132.

Dagnac, Anne. 2019. French. In Jeroen van Craenenbroeck \& Tanja Temmerman (eds.), The Oxford Handbook of Ellipsis, Oxford: Oxford University Press. DOI: https://doi. org/10.1093/oxfordhb/9780198712398.001.0001

Diller, Anne Marie. 1984. La pragmatique des questions et des réponses: Mit einer Zusammenfassung in englischer Sprache, vol. 243. Gunter Narr Verlag.

Dubinsky, Stanley \& Robert Hamilton. 1998. Epithets as antilogophoric pronouns. Linguistic Inquiry 29(4). 685-693. DOI: https://doi.org/10.1162/002438998553923 
Farkas, Donka. 1992. On obviation. Lexical matters 1. 85-109.

Farkas, Donka. 2011. Polarity particles in English and Romanian. In Julia Herschensohn (ed.), Romance linguistics 2010: Selected papers from the 40th Linguistic Symposium on Romance Linguistics, vol. 318 (Current Issues in Linguistic Theory), 303-328. Seattle, WA: John Benjamins. DOI: https://doi.org/10.1075/cilt.318.19far

Frascarelli, Mara. 2004. Dislocation, clitic resumption and minimality: a comparative analysis of left and right topic constructions in Italian. In B. Kampers-Manhe, R. Bok-Bennema, B. Hollebrandse \& P. Sleeman (eds.), Romance languages and linguistic theory 2002, 99-118. Amsterdam/Philadelphia: John Benjamins.

Ginzburg, Jonathan \& Ivan A. Sag. 2000. Interrogative Investigations: the form, meaning, and use of English interrogatives. CSLI Publications.

Goodhue, Daniel \& Michael Wagner. 2018. Intonation, yes and no. Glossa: A Journal of General Linguistics 3(1). DOI: https://doi.org/10.5334/gjgl.210

Grevisse, Maurice \& André Goosse. 2007. Le Bon Usage. Bruxelles: Duculot. 14th edn.

Hankamer, Jorge. 1979. Deletion in coordinate structure. New York: Garland.

Hoeybye, Paul. 1939. Oui, si et non. Le français moderne 7. 47-51.

Holmberg, Anders. 2001. The syntax of yes and no in Finnish. Studia Linguistica. DOI: https://doi.org/10.1111/1467-9582.00077

Holmberg, Anders. 2011. On the syntax of yes and no in English. Manuscript. Newcastle University.

Holmberg, Anders. 2013. The syntax of answers to polar questions in English and Swedish. Lingua 128(128). 31-50. DOI: https://doi.org/10.1016/j.lingua.2012.10.018

Kerbrat-Orecchioni, Catherine. 2001. Oui, non, si: un trio célèbre et méconnu. Marges linguistiques 2. 95-119.

Kramer, Ruth \& Kyle Rawlins. 2010. Polarity particles and ellipsis: a (somewhat) crosslinguistic perspective. Handout presented at the polarity particles workshop at UCSC, Jan 16, 2010.

Kramer, Ruth \& Kyle Rawlins. 2011. Polarity particles: an ellipsis account. In Suzi Lima, Kevin Mullin \& Brian Smith (eds.), Proceedings of the North Eastern Linguistics Society 39. 479-492. Amherst, MA: GLSA.

Krifka, Manfred. 2013. Response particles as propositional anaphors. In Todd Snider (ed.), Proceedings of Semantics and Linguistic Theory 23. 1-18. Washington, DC: Linguistic Society of America. DOI: https://doi.org/10.3765/salt.v23i0.2676

Laka, Itziar. 1990. Negation in Syntax: On the Nature of Functional Categories and Projections. Cambridge, MA: MIT dissertation.

Lebaud, Daniel. 1995. Mais oui... Eh non... Ben si ! ou ce que TU dois penser quand JE te réponds. Bulletin de linguistique appliquée et générale 21. 141-161.

Merchant, Jason. 2001. The Syntax of Silence: Sluicing, Islands, and the Theory of Ellipsis. Oxford: Oxford University Press.

Merchant, Jason. 2005. Fragments and ellipsis. Linguistics and philosophy 27(6). 661-738. DOI: https://doi.org/10.1007/s10988-005-7378-3

Morin, Yves-Charles. 1985. On the two French subjectless verbs voici and voilà. Language, 777-820. DOI: https://doi.org/10.2307/414490

Morris, Amanda. 2008. Polarity Ellipsis and Negative Stripping. Manuscript. Pasquereau, Jérémy. 2018. Responding to questions and assertions: embedded Polar Response Particles, ellipsis, and contrast. Amherst, MA: University of Massachusetts dissertation.

Pasquereau, Jérémy. 2020. French polar response particles and neg-movement. Natural Language Semantics.

Plantin, Christían. 1982. Oui et non sont-ils des pro-phrases? Remarques sur leur fonctionnement dans les dialogues. Français (Le) Moderne Paris 50(3). 252-265. 
Pohl, Jacques. 1976. Matériaux pour l'histoire du système oui, non, si. Kwartalnik Neofilologiczny.

Potts, Christopher. 2005. The logic of conventional implicatures. Oxford: Oxford University Press. DOI: https://doi.org/10.1093/acprof:oso/9780199273829.001.0001

Rizzi, Luigi. 1990. On the anaphor-agreement effect. Rivista di linguistica 2(1). 27-42.

Rizzi, Luigi. 1997. The fine structure of the left periphery. In Liliane Haegeman (ed.), Elements of grammar: handbook in generative syntax, 281-337. Dordrecht: Kluwer. DOI: https://doi.org/10.1007/978-94-011-5420-8_7

Rizzi, Luigi. 2001. On the position "Int(errogative)" in the left periphery of the clause. Current studies in Italian syntax: Essays offered to Lorenzo Renzi 59. 287-296.

Roelofsen, Floris \& Donka Farkas. 2014. Polarity particle responses as a window onto the interpretation of questions and assertions. Language 91(2). 359-414. DOI: https://doi. org/10.1353/lan.2015.0017

Rowlett, Paul. 2007. The Syntax of French. Cambridge: Cambridge University Press. DOI: https://doi.org/10.1017/CBO9780511618642

Ruwet, Nicolas. 1984. Je veux partir/* je veux que je parte. A propos de la distribution des complétives à temps fini et des compléments à l'infinitif en français. Cahiers de grammaire 7. 75-138.

Schapira, Charlotte. 2012. Quand oui et non ne sont pas des réponses: construction de l' interlocuteur et polyphonie. In Catherine Douay \& Daniel Roulland (eds.), L' interlocution comme paramètre, Presses universitaires de Rennes.

Schlenker, Philippe. 2005. The lazy Frenchman's approach to the subjunctive. In Twan Geerts, Ivo van Ginneken \& Haike Jacobs (eds.), Romance Languages and Linguistic Theory 2003, vol. 270 (Current Issues in Linguistic Theory), 269-309. John Benjamins.

Schwarzschild, Roger. 1999. Givenness, AvoidF and Other Constraints on the Placement of Accent. Natural Language Semantics 7. 141-177. DOI: https://doi.org/10.1023/ A:1008370902407

Servidio, Emilio. 2014. Polarity particles in Italian: Focus, Fragments, Tags. Siena: Università di Siena dissertation.

Suñer, Margarita. 1986. On the referential properties of embedded finite clause subjects. Generative studies in Spanish syntax, 183-196. DOI: https://doi.org/10.1515/ 9783110859232-012

Takagaki, Yumi. 2014. Oui au lieu de si: les usages exceptionnels de oui/si/non dans les textes écrits. In SHS Web of Conferences 8. 2917-2932. EDP Sciences. DOI: https://doi. org/10.1051/shsconf/20140801180

Thoms, Gary. 2012. Yes and no, merge and move, ellipsis and parallelism. Handout given at the Workshop on the Syntax of Answers to Polar Questions, Newcastle University.

Vicente, Luis. 2006. Short negative replies in Spanish. Linguistics in the Netherlands 23(1). 199-211. DOI: https://doi.org/10.1075/avt.23.20vic

Wilmet, Marc. 1976. Oui, si et non en français moderne. Le français moderne 44. 229-253. Wiltschko, Martina. 2017. Response particles beyond answering. In Laura R. Bailey \& Michelle Sheehan (eds.), Order and structure in syntax, 241-280. Berlin: Language Science Press. http://syntaxofspeechacts.linguistics.ubc.ca/wp-content/uploads/2014/02/ responseparticles-beyond-answering.pdf.

Wunderli, Peter. 1974. Syntaxe transphrastique: fr. 'non'. Studii şi cercetări lingvistice, 25.

Zwanenburg, W. 1967. Voici, voilà en oui, si, non. Inaugural lecture given at the university of Groningen. 
How to cite this article: Pasquereau, Jérémy. 2020. Polar response particles in French as remnants of ellipsis. Glossa: a journal of general linguistics 5(1): 101.1-32. DOI: https://doi.org/10.5334/gjgl.1064

\section{Submitted: 08 August 2019 Accepted: 23 July 2020 Published: 15 October 2020}

Copyright: $\odot 2020$ The Author(s). This is an open-access article distributed under the terms of the Creative Commons Attribution 4.0 International License (CC-BY 4.0), which permits unrestricted use, distribution, and reproduction in any medium, provided the original author and source are credited. See http://creativecommons.org/licenses/by/4.0/.

$\mathrm{u}[\quad$ Glossa: a journal of general linguistics is a peer-reviewed open access journal published by Ubiquity Press. 